OPEN

SUBJECT AREAS:

NEURONAL PHYSIOLOGY

HORMONE RECEPTORS

Received

5 September 2014

Accepted

18 December 2014

Published

19 January 2015

Correspondence and requests for materials should be addressed to R.V.S.R. (raju-rajala@ ouhsc.edu)

\section{Effect of Knocking Down the Insulin Receptor on Mouse Rod Responses}

\author{
Michael L. Woodruff', Ammaji Rajala², Gordon L. Fain ${ }^{1,5}$ \& Raju V. S. Rajala ${ }^{2,3,4}$
}

\begin{abstract}
'Department of Integrative Biology and Physiology, University of California Los Angeles, Los Angeles, California, 90095-7239, ${ }^{2}$ Department of Ophthalmology, University of Oklahoma Health Sciences Center, Oklahoma City, Oklahoma 73 104, ${ }^{3}$ Department of Physiology and University of Oklahoma Health Sciences Center, Oklahoma City, Oklahoma 73104, ${ }^{4}$ Department of Cell Biology, University of Oklahoma Health Sciences Center, Oklahoma City, Oklahoma 73 104, ${ }^{5}$ Department of Ophthalmology and Jules Stein Eye Institute, University of California Los Angeles, Los Angeles, California, 90095-7000.
\end{abstract}

Previous experiments have shown that the insulin receptor (IR) is expressed in mammalian rods and contributes to the protection of photoreceptors during bright-light exposure. The role of the insulin receptor in the production of the light response is however unknown. We have used suction-electrode recording to examine the responses of rods after conditionally knocking down the insulin receptor. Our results show that these $I R$ knock-down rods have an accelerated decay of the light response and a small decrease in sensitivity by comparison to littermate WT rods. Our results indicate that the insulin receptor may have some role in controlling the rate of rod response decay, but they exclude a major role of the insulin receptor pathway in phototransduction.

$\mathrm{P}$ hotoreceptor cyclic nucleotide-gated (CNG) channels are critical elements in phototransduction and light adaptation ${ }^{1,5}$. They are responsible for generating the light response in photoreceptors and are directly and co-operatively gated by cGMP. The CNG channel sensitivity to cGMP has been studied extensively and has been shown to depend on or to be regulated by several factors, including $\mathrm{Ca}^{2+} / \mathrm{CaM}^{6,7}$, divalent ions ${ }^{8,9}$, diacylglycerol $^{10}$, phospholipids ${ }^{11}$, phosphorylation ${ }^{12,13}$ and Grb14 ${ }^{14,15}$. The insulin receptor (IR) can also regulate olfactory $^{16,17}$ and cone CNG channels ${ }^{18}$ through phosphoinositide 3-kinase.

IRs are expressed in the inner and outer segments of rod and cone photoreceptors and are localized to the plasma membrane $e^{19,20}$. IR is a receptor tyrosine kinase, and in retina it is constitutively autophosphorylated (activated) independent of its ligand insulin ${ }^{21,22}$. In the dark, IR activation is negatively regulated by two proteins, protein tyrosine phosphatase (PTP1B ${ }^{23}$ and an adapter protein-growth factor receptor-bound protein 14 $(\text { Grb14 })^{24}$. PTP1B dephosphorylates phosphotyrosine groups on the IR, while the non-phosphorylated form of Grb14 binds to the active site of the IR and inactivates IR signaling ${ }^{25,26}$.

In light, stimulation of rhodopsin activates the non-receptor tyrosine kinase $\operatorname{Src}^{27,28}$ to phosphorylate Grb14. Phosphorylated Grb14 unbinds from IR and binds to the active site of PTP1B, down-regulating its phosphatase activity ${ }^{27}$ and thereby preventing the dephosphorylation of the $\mathrm{IR}^{28}$. The IR signaling pathway requires the photobleaching of rhodopsin but not transducin signaling ${ }^{19}$. We have previously reported that IR directly phosphorylates the cyclic nucleotide-gated channel alpha subunit (CNGA1), causing the channel to become less sensitive to cGMP so that more channels are closed at any given cGMP concentration ${ }^{29}$. In vitro kinetic and biochemical assays on rod outer-segment membrane vesicles suggest that the channels may be more sensitive to cGMP and open at a lower concentration of cGMP in $I R^{-1 /}$ mice $^{29}$; however, the functional consequence of IR on the cyclic nucleotide-gated channels in rod physiology in vivo has not been previously investigated.

In this study, we explored the function of IR in rod photoreceptors by recording electrical responses from rods in which the gene for the IR protein had been knocked down. We discovered that rod responses from IR knockdown mice recover after illumination more rapidly than responses of wild-type (WT) mouse rods, as expected if the channels are more sensitive to cGMP and open at a lower concentration after knocking down the $I R$ gene. Much to our surprise, however, the effect of knocking down the $I R$ gene was similar in dark-adapted and lightadapted animals and seemed to be the result at least in part of an effect on the rod phosphodiesterase, much like our previous results on rods lacking Grb1 $4^{15}$. Collectively, our studies indicate an effect of the non-canonical IR/ Grb14 pathway on rod function but exclude a major role of these proteins in producing the electrical response of the rods. 


\section{Methods}

Materials. Antibodies. Monoclonal anti-IR antibody was obtained from Cell Signaling (Danvers, MA). Anti-PDE6 $\beta$ and anti-transducin alpha subunit antibodies were obtained from Santa Cruz Biotechnology (Santa Cruz, CA). Anti-PDE $\gamma$ and anti-actin antibodies were obtained from Affinity BioReagents (Golden, CO). AntiCNGA1 and anti-opsin (1D4) antibodies were kindly provided by Dr. Robert Molday (University of British Columbia, Vancouver, Canada). The GAP protein antibodies (RGS9-1, GB5 $\mathrm{L}, \mathrm{G} \beta 5_{\mathrm{S}}$ and R9AP) were kindly provided by Dr. Theodore G. Wensel (Baylor College of Medicine, Houston). The guanylyl cyclase1 (GC1) and guanylyl cyclase activating protein 1 (GCAP1) antibodies were kindly provided by Dr. Seifollah Azadi (University of Oklahoma, Oklahoma City).

Animals. All animal work was in strict accordance with the NIH Guide for the Care and Use of Laboratory Animals, and the Association for Research in Vision and Ophthalmology Statement on the Use of Animals in Vision Research. All protocols were approved by the IACUC of the University of Oklahoma Health Sciences Center, the Dean A. McGee Eye Institute, and the University of California Los Angeles.

Generation of photoreceptor-specific conditional insulin receptor knock-down mice. Photoreceptor-specific conditional insulin receptor knock-down mice were prepared as previously described with the Cre-lox technique ${ }^{30}$, by mating animals having a floxed insulin receptor with mice containing Cre recombinase under the control of the $0.2-\mathrm{kb}$ mouse opsin promoter ${ }^{31}$ (Fig. 1A). The targeting vector was constructed with the mouse $I R$ gene in which a selection cassette flanked by loxP sites was introduced upstream of exon 4 with a third loxP site downstream of exon $4^{32}$. In the presence of Cre recombinase, floxed exon 4 of the $I R$ allele would be deleted, thereby causing a frame shift mutation and an immediate stop of translation. The predicted product of this gene, if one exists at all, would represent a 308 amino acid fragment of the $\mathrm{N}$-terminus of the IR $\alpha$-subunit, lacking a high-affinity binding site and the transmembrane and kinase domains.
To create photoreceptor-specific IR knock-down mice, the floxed IR mice carrying the cre transgene were bred with the IR-floxed homozygous mice (backcross). The genotype of the photoreceptor-specific $I R$ knock-down mice (i.e., animals carrying the cre transgene and homozygous for the IR-floxed allele) was confirmed by PCR analysis of tail DNA. To identify rhodopsin-cre, PCR was performed with $1 \mu \mathrm{l}$ of genomic DNA and sense ( $5^{\prime}$-GGT CAG TGC CTG GAG TTG CG-3') and antisense $\left(5^{\prime}\right.$-GCC TCC ACC CGA TGT CAC C-3') primers to amplify a 600 -bp product. To identify IR-floxed mice, we used sense ( $5^{\prime}$-GAT GTG CAC CCC ATG TCT G-3') and antisense ( $5^{\prime}$-CTG AAT AGC TGA GAC CAC AG-3') primers to amplify genomic DNA by PCR. The wild-type allele generates a 280 -bp product, and the floxed allele generates a 300 -bp product. Our conditional deletion strategy did not completely eliminate the protein in rods, but some residual IR expression can still be seen.

Therefore, we called these mice $I R$ knock-down mice instead of knockout mice. The conditional IR knock-down mice on a mixed genetic background were bred for six generations with $\mathrm{BALB} / \mathrm{c}$ mice to generate mice with an albino background. Animals were born in the animal facility in 60-lux cyclic light (12 h on/off) and maintained under these lighting conditions until they were used in an experiment. Control recordings from BALB/c mice were always made from littermates of the $I R$ knockdown mice used in our experiments.

Immunoblot Analysis. Retinas from wild type and IR knock-down mice were homogenized in a lysis buffer containing $1 \%$ Triton X-100, $137 \mathrm{mM} \mathrm{NaCl}, 20 \mathrm{mM}$ Tris- $\mathrm{HCl}$ ( $\mathrm{pH} 8.0$ ), 10\% glycerol, $1 \mathrm{mM}$ EGTA, 1 mM MgCl, $1 \mathrm{mM}$ phenylmethylsulfonyl fluoride, $0.2 \mathrm{mM} \mathrm{Na}_{3} \mathrm{VO}_{4}, 10 \mu \mathrm{g} / \mathrm{ml}$ leupeptin, and $1 \mu \mathrm{g} / \mathrm{ml}$ aproti$\operatorname{nin}^{33}$. Insoluble material was removed by centrifugation at $17,000 \times \mathrm{g}$ for $20 \mathrm{~min}$ at $4^{\circ} \mathrm{C}$, and the protein concentrations of the solubilized proteins were determined by the Bicinchoninic Acid reagent following the manufacturer's instructions (Pierce Biotechnology, Rockford, IL). Proteins were resolved by $10 \%$ or gradient (4-20\%) SDS-PAGE and transferred to nitrocellulose membranes. The blots were washed twice for $10 \mathrm{~min}$ with TTBS $(20 \mathrm{mM}$ Tris- $\mathrm{HCl}$ at $\mathrm{pH} 7.4,100 \mathrm{mM} \mathrm{NaCl}$ and $0.1 \%$ Tween-20) and blocked with either $5 \%$ bovine serum albumin or non-fat dry milk
Conditional Deletion of Rod Photoreceptor IR
A

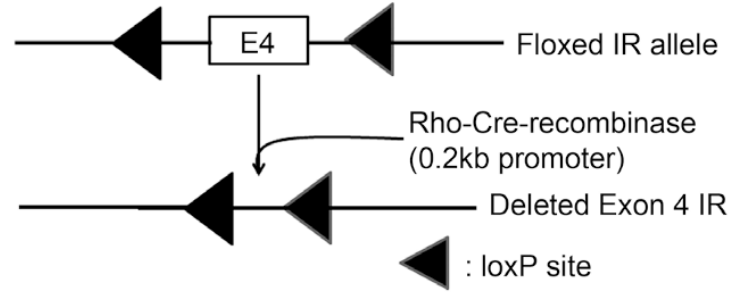

IR WT

IR KD
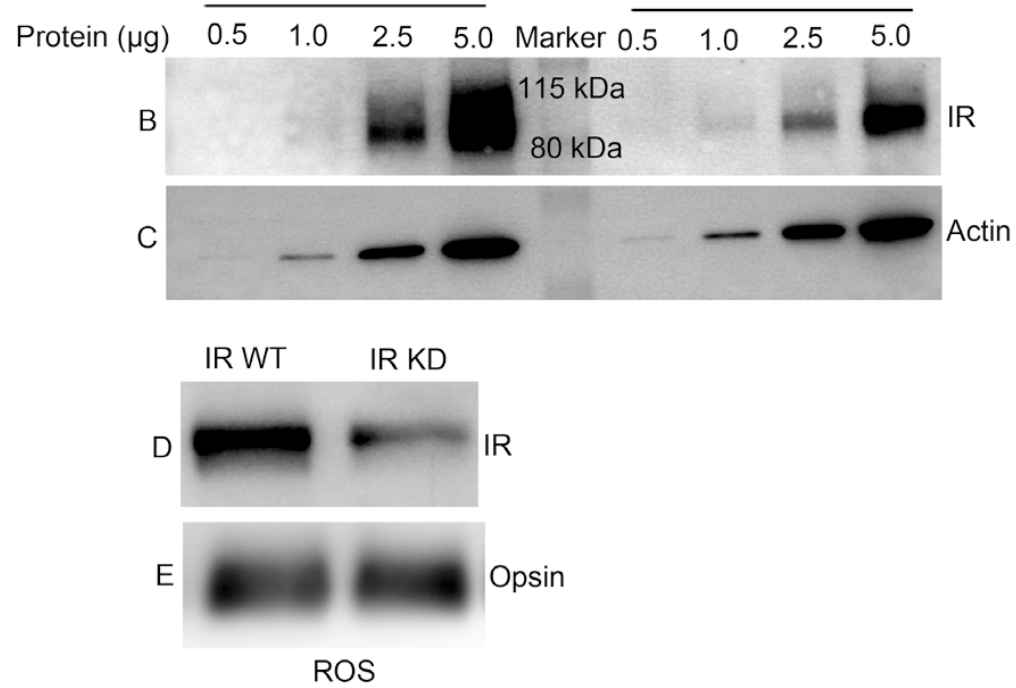

Figure $1 \mid$ Expression levels of transduction proteins in wild type and $I R$ knock-down animals. (A) Schematic diagram of loxP floxed IR loci. Rodphotoreceptor-specific $I R$ knock-down mice were generated by breeding mice with a floxed IR with mice that express Cre recombinase under the control of rod opsin promoter $(0.2 \mathrm{~kb})$. To determine the deletion of IR, varying amounts of retinal proteins $(0.5,1.0,2.5$ and $5.0 \mu \mathrm{g})$ from IR wild type and $I R$ knock-down (IR-KD) mouse retinas were subjected to immunoblot analysis with antibodies against $(B)$ IR and $(C)$ actin. Rod outer segments (ROS) were prepared by discontinuous sucrose $(47 \%, 37 \%$ and $32 \%$ ) density gradient centrifugation (see Methods). ROS from IR wild type and $I R$ knock-down mice were immunoblotted with $(D)$ anti-IR and $(E)$ anti-opsin antibodies. Ten micrograms of two independent retinal proteins were subjected to immunoblot

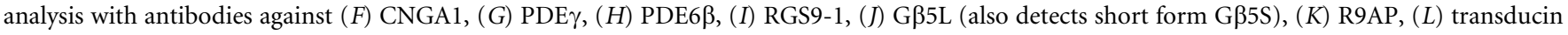
alpha, $(M)$ GC1, (N) GCAP1, and $(O)$ actin. For Fig. 1F, the blot is a reprobe of the gel used for PDE6 $\beta(H)$; that is, after the PDE6 $\beta$ measurement, the gel was stripped and reprobed with an anti-CNGA1 antibody. Full-length blots/gels are presented in Supplementary Figure 1. 
powder (Bio-Rad) in TTBS for $1 \mathrm{~h}$ at room temperature. Blots were then incubated with anti-IR $(1: 1000)$, anti-CNGA1 $(1: 1000)$, anti-PDE $\gamma(1: 1000)$, anti-PDE6 $\beta$, anti-RGS9-1 ( $1: 1000)$, anti-G $\beta 5_{\mathrm{L}}$ and anti-G $\beta 5_{\mathrm{S}}(1: 1000)$, anti-R9AP $(1: 1000)$, anti-transducin alpha $(1: 1000)$, anti GC1 $(1: 1000)$, anti-GCAP1 $(1: 1000)$, and antiactin $(1: 1000)$ antibodies for $1 \mathrm{~h}$ at room temperature. Following primary antibody incubations, immunoblots were incubated with HRP-linked secondary antibodies (mouse or rabbit or goat) and developed by enhanced chemiluminescence according to the manufacturer's instructions.

Preparation of Mouse Rod Outer Segments. ROS were prepared from mouse retinas with discontinuous sucrose gradient centrifugation as previously described ${ }^{19}$. Eight retinas from 4 mice were homogenized in $1.25 \mathrm{ml}$ of ice-cold $47 \%$ sucrose solution containing $100 \mathrm{mM} \mathrm{NaCl}, 1 \mathrm{mM}$ EDTA, $1 \mathrm{mM}$ phenylmethylsulfonyl fluoride (PMSF), and $10 \mathrm{mM}$ Tris-HCl (pH 7.4) (buffer A). Retinal homogenates were transferred to $4.5-\mathrm{ml}$ centrifuge tubes and sequentially overlaid with $1.5 \mathrm{ml}$ of $37 \%$, and $1.0 \mathrm{ml}$ of $32 \%$ sucrose dissolved in buffer A. The gradients were spun at $82,000 \times$ $\mathrm{g}$ for $90 \mathrm{~min}$ at $4{ }^{\circ} \mathrm{C}$. The $32 \% / 37 \%$ interfacial sucrose band containing ROS membranes was harvested and diluted with $10 \mathrm{mM}$ Tris- $\mathrm{HCl}$ (pH 7.4) containing $100 \mathrm{mM}$ $\mathrm{NaCl}$, and $1 \mathrm{mM}$ EDTA, and it was centrifuged at $27,000 \times \mathrm{g}$ for $30 \mathrm{~min}$. The ROS pellets were resuspended in $10 \mathrm{mM}$ Tris- $\mathrm{HCl}$ ( $\mathrm{pH}$ 7.4) containing $100 \mathrm{mM} \mathrm{NaCl}$, and $1 \mathrm{mM}$ EDTA and stored at $-20^{\circ} \mathrm{C}$. Protein concentrations were determined with the $\mathrm{BCA}$ reagent from Pierce (Pierce, Rockford, IL) in accordance with the manufacturer's instructions.

Suction-Electrode Recordings. Suction-electrode recordings were made from single mouse rods by methods previously described ${ }^{34-36}$. IR knock-down and WT littermates between 2 and 6 months of age were dark adapted typically for $5 \mathrm{~h}$ but for at least $3 \mathrm{~h}$ in a light-tight box. Rods were perfused at $37-39^{\circ} \mathrm{C}$ with DMEM (catalog \#D-2902, Sigma, St. Louis, MO) supplemented with $15 \mathrm{mM} \mathrm{NaHCO}_{3}, 2 \mathrm{mM} \mathrm{Na}$ succinate, $0.5 \mathrm{mM} \mathrm{Na}$ glutamate, $2 \mathrm{mM} \mathrm{Na}$ gluconate, and $5 \mathrm{mM} \mathrm{NaCl}$, bubbled with $5 \% \mathrm{CO}_{2}, \mathrm{pH}$ 7.4. Data were filtered at $30 \mathrm{~Hz}$ (8 pole Bessel filter) and sampled at $100 \mathrm{~Hz}$. Flashes of $500 \mathrm{~nm}$ light $20 \mathrm{~ms}$ in duration were attenuated to different light levels by absorptive neutral density filters. A $500 \mathrm{~nm}$ light was also used for steps of light and for bleaching. The amount of bleaching was determined as in previous experiments ${ }^{37}$ from the photosensitivity of mouse rods of $5.7 \times 10^{-9} \mu \mathrm{m}^{238}$

Sensitivity was calculated by dividing the mean response to a dim intensity flash (less than 0.2 of maximum current) by the intensity of the stimulating flash. The values of $\tau_{D}$ for dark-adapted WT and IR knock-down rods were measured as in Woodruff et al. ${ }^{34}$ from a series of five flashes each at 7 intensities, chosen for each rod to fall within one and a half log units above the flash intensity that just produced saturation of the rod response amplitude. Flash intensities were in the range of 159-3250 photons $\mu \mathrm{m}^{-2}$. The time in saturation $\left(T_{\mathrm{sat}}\right)$ was measured as the time from the beginning of the flash to the time at which the mean circulating current recovered to $25 \%$ of its dark-adapted value. The value of $\tau_{D}$ was then calculated rod by rod or from mean values as the best-fitting slope of $T_{\text {sat }}$ versus the natural logarithm of the flash intensity ${ }^{39}$. Single-photon responses were calculated from the squared mean and variance of the response as described previously ${ }^{40,41}$. Unless otherwise stated, errors are given as standard errors of the mean. Curve fitting and plotting of data were done with the program Origin (OriginLab, Northampton, MA).

\section{Results}

Photoreceptor-specific conditional insulin-receptor knock-down mice were prepared as previously described ${ }^{30}$. In Fig. 1, we show expression levels of photoreceptor outer segment proteins in whole retinas from $I R$ knock-down and littermate control animals. Panel $B$ in the gel shows decreased expression of the IR protein in the retinas of rod-specific $I R$ knock-down mouse retinas compared to littermate controls. The remaining expression in $I R$ knock-down retinas is produced by cells of the inner layers of the retina. To evaluate the efficiency of knocking down the IR in rod photoreceptors as a result of rhodopsin-driven Cre expression, rod outer segment (ROS) membranes were prepared from IR wild type and $I R$ knock-down mice and were subjected to inmmunoblot analysis with anti-IR and antiopsin antibodies (Figs. $1 D$ and $1 E$ ). The results indicate a decrease in the expression of IR in ROS from IR knock-down retinas. We could observe some expression of IR even in IR knock-down ROS, perhaps as a result of some contamination from inner retinal cells.

To insure that the knocking down of the $I R$ gene had no effect on the expression of any of the other transduction proteins, we examined the expression levels of CNGA1, PDE6 $\beta, P D E \gamma$, transducing alpha, RGS9-1, G $\beta 5 \mathrm{~L}$ (also recognizes short form), G $\beta 5$ S and R9AP (Figs. $1 F-1 L$ ). We also examined whether there was an effect of IR on the regulation of cGMP synthesis and the sensitivity of cGMP to $\mathrm{Ca}^{2+}$ by determining the expression levels of guanylyl cyclase1 (GC1) and guanylyl cyclase activating protein 1 (GCAP1) in IR knock-down retinas. The results indicated that there was no difference in their expression levels by comparison with $I R$ knock-down control retinas (Fig. $1 M, N$ ). Actin expression was used as an internal control (Fig. 1O). Our results appear to show no differences in the expression levels of transduction proteins between WT and IR knock-down animals.

Recent experiments have indicated that rod-specific iCre75 transgenic mice contain a second transgene that results in greatly enhanced expression of the GTPase accelerating protein R9AP, resulting in accelerated photoreceptor response decay ${ }^{42}$. Even though we used a different rod-specific Cre-recombinase mouse line in the preparation of our IR knock-down mice ${ }^{30}$, we performed additional experiments to control for over-expression of R9AP in our IR knockdown animals. The data in Figs. $2 A-2 B$ show a concentration series of protein expression for actin and R9AP. We could not detect any significant increase in R9AP expression in our animals (Fig. 2C). Since overexpression of PDE $\gamma$ can also accelerate response decay ${ }^{41}$, we also carefully examined PDE $\gamma$ expression in our IR knock-down animals (Figs. 2D-2E). The concentration series of protein expression shows that there is no significant increase in expression of PDE $\gamma$ (Fig. 2F).

In Fig. 3, we compare mean responses to a graded series of flash intensities in dark-adapted littermate WT rods (Fig. $3 A$ ) and darkadapted $I R$ knock-down rods (Fig. $3 C$ ). The amplitudes and waveforms of the responses were similar, though IR knock-down rods decayed more rapidly than WT rods and were less sensitive to light. For WT littermate controls, the mean dark-adapted dim-flash sensitivity was $0.32 \pm 0.05 \mathrm{pA}$ photon ${ }^{-1} \mu \mathrm{m}^{2}$ (mean $\pm \mathrm{SE}, \mathrm{n}=23$ ), whereas for the $I R$ knock-down rods the mean sensitivity was 0.16 $\pm 0.07 \mathrm{pA}$ photon $^{-1} \mu \mathrm{m}^{2}(\mathrm{n}=19)$. These values were significantly different ( $\mathrm{T}$ test, $\mathrm{p}=0.015)$. Sensitivity normalized to circulating current was also calculated on a cell-by-cell basis and was $0.022 \pm$ 0.003 photon $^{-1} \mu \mathrm{m}^{2}$ for WT rods and $0.011 \pm 0.001$ photon $^{-1} \mu \mathrm{m}^{2}$ for IR knock-down rods; these values were again significantly different. Although the mean circulating current of $I R$ knock-down rods was somewhat larger than WT rods, this difference was not significant ( $\mathrm{T}$ test, $\mathrm{p}=0.15$ ).

Our previous experiments have shown that the IR can be activated by bright light exposure. We therefore also compare in Fig. 3 responses at steady-state after a $50 \%$ bleach of the photopigment in WT rods (Fig. 3B) and IR knock-down rods (Fig. 3D). Bleaching decreases the amplitude of the response and accelerates the rate of response decay in WT rods $^{37}$ as well as in $I R$ knock-down rods (Fig. $3 D$ ), but bleached $I R$ knock-down rods decayed somewhat more rapidly than bleached WT rods and were less sensitive. Thus knocking down the gene for the insulin receptor had similar effects on both dark-adapted and light-adapted photoreceptors.

In Fig. $4 A$, we compare mean single-photon responses of WT littermate control rods and $I R$ knock-down rods. The mean amplitude of the single-photon response calculated rod by rod was $0.74 \pm$ 0.09 for WT rods $(\mathrm{n}=14)$ and $0.65 \pm 0.07$ for $I R$ knock-down rods $(\mathrm{n}=16)$. The single-photon response of the $I R$ knock-down rods was therefore somewhat smaller and decayed more rapidly. The declining phases of the two mean responses have been fit with single-exponential decay functions. The time constant of decay $\left(\tau_{\mathrm{REC}}\right)$ was smaller for IR knock-down rods than for WT rods. Mean time constants from single-photon responses measured cell by cell were $214 \pm$ $18 \mathrm{~ms}$ for WT rods and $157 \pm 15 \mathrm{~ms}$ for $I R$ knock-down rods.

In Fig. $4 B$ we explore this difference in greater detail by plotting the mean value of $\tau_{\mathrm{REC}}$ as a function of flash intensity. Although there was some variability from one intensity to another, the values of $\tau_{\text {REC }}$ were systematically smaller for $I R$ knock-down rods than for WT rods. We also show in Fig. $4 B$ the values of $\tau_{\text {REC }}$ for rods lacking the gene for the Grb14 protein, which our previous study showed also to exhibit accelerated response decay ${ }^{15}$. The values of $\tau_{\mathrm{REC}}$ for $I R$ knockdown rods and $G r b 14^{-1-}$ rods were comparable and were both uniformly smaller than for WT rods. The limiting time constant $\left(\tau_{D}\right)$ 


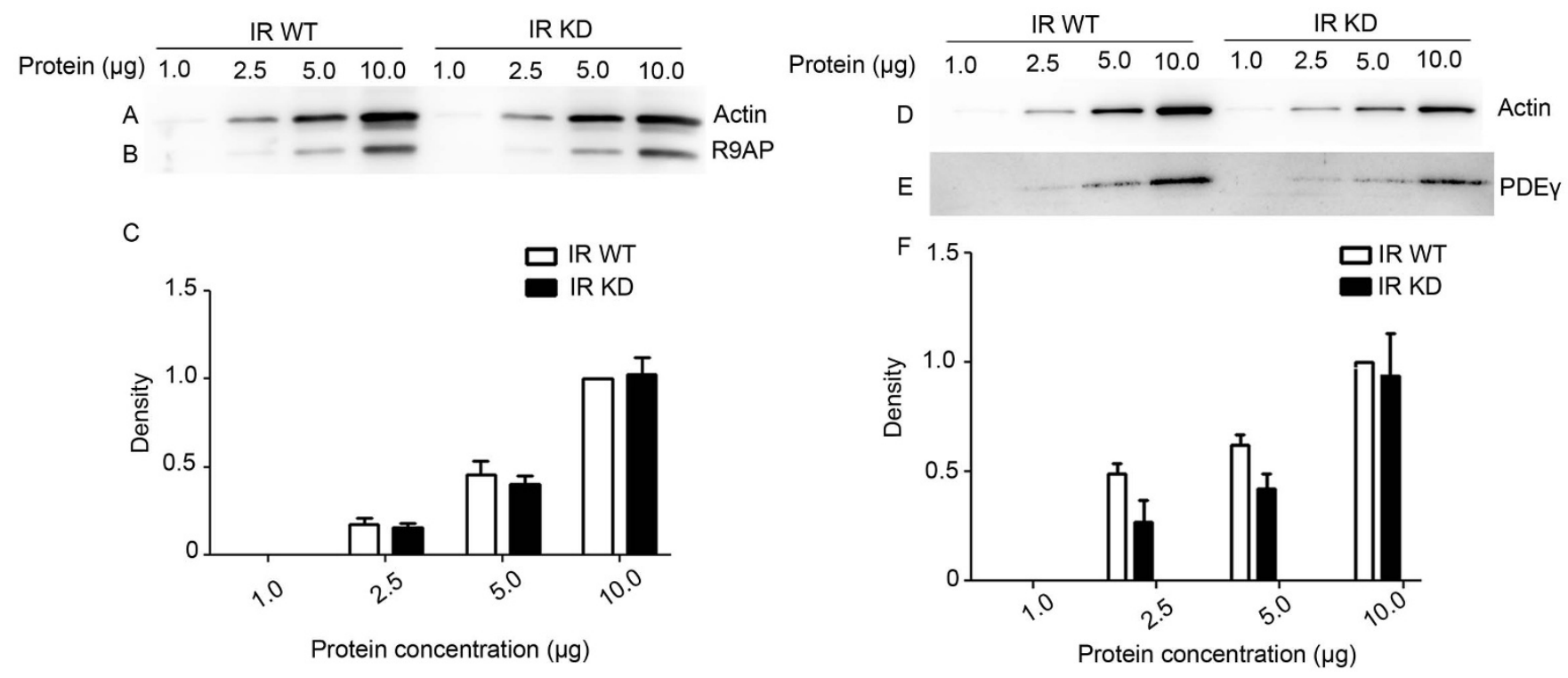

Figure $2 \mid$ Concentration series of R9AP and PDE $\gamma$ expression in retinal homogenates of wild type and IR knock-down animals. For each line, 1.0, 2.5, 5.0 and $10.0 \mu \mathrm{g}$ of protein was loaded, and subjected to immunoblot analysis with antibodies against $(B) \mathrm{R} 9 \mathrm{AP},(E) \mathrm{PDE} \gamma$, and $(A, D)$ actin. The blots shown are representative of four retinas examined from wild type and $I R$ knock-down (IR-KD) animals. Representative immunoblots quantifying the expression of $(C)$ R9AP and $(F)$ PDE $\gamma$ in retinal homogenates of WT and $I R$ knock-down animals. For each line, 1.0, 2.5, 5.0 and 10.0 $\mu$ g of protein was loaded. Densitometric analysis of the R9AP and PDE $\gamma$ immunoblots was performed in the linear range of detection and potted as values of band intensity versus protein concentration. Data are mean and SEM for 4 wild type and 4 IR knock-down animals. Ten microgram protein concentration of wild type was set as 1.0. A Student's t-test was used to show that there were no significant differences in the expression level of R9AP and PDE $\gamma$ at different concentrations between wild type and $I R$ knock-down animals. Full-length blots/gels are presented in Supplementary Figure 2.
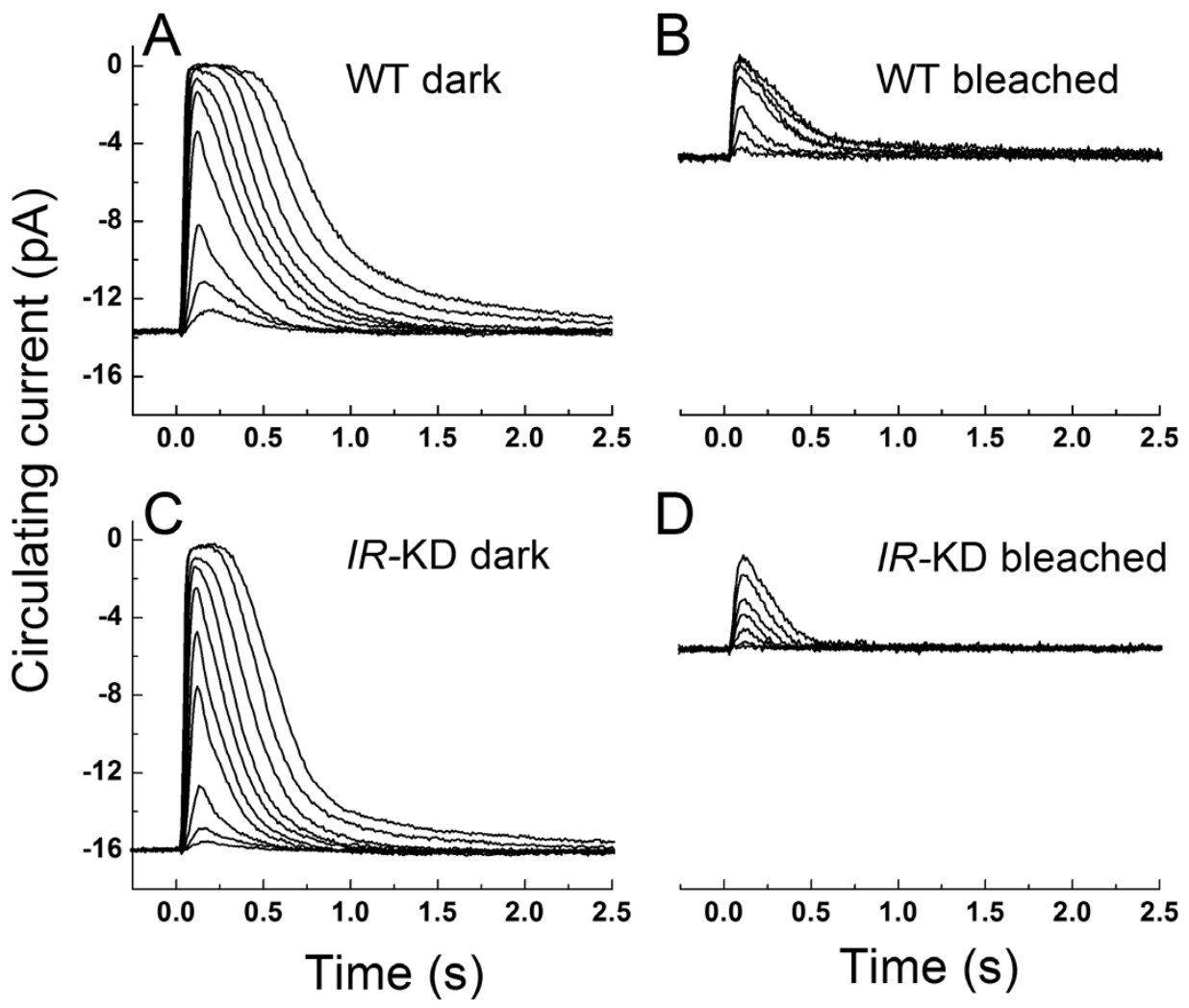

Figure 3 Rod responses to 20-ms flashes of 500-nm light for IR knock-down and control rods under dark-adapted and bleach-adapted conditions. (A), dark-adapted WT strain control at flash intensities of 2.6, 8.6, 23, 75, 130, 236, 430, 783, 1530, and 2780 photons $\mu \mathrm{m}^{-2}$. Traces are mean

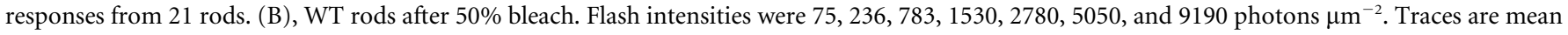
responses from 9 rods. (C), dark-adapted $I R$ knock-down rods at same flash intensities as in $A$. Traces are mean responses from 16 rods. $D, I R$ knock-down (IR-KD) rods after $50 \%$ bleach. Flash intensities were same as in $C$. Traces are mean responses from 8 rods. 

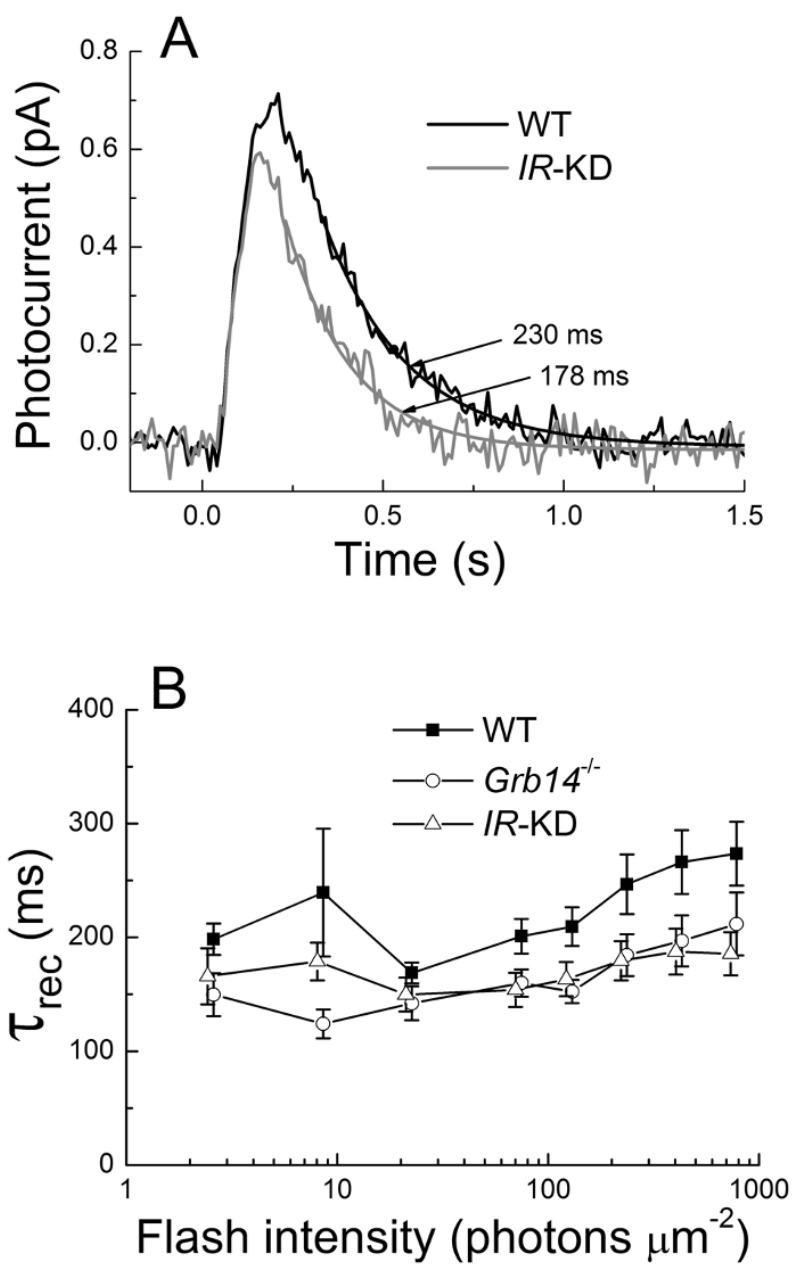

Figure $4 \mid I R$ knock-down rods have a more rapid rate of response recovery than WT rods. (A), mean single-photon responses of $14 \mathrm{WT}$ rods (black) and 16 IR knock-down (IR-KD) rods (gray), calculated from squared mean and variance as in $(39,40)$. Arrows point to best-fitting single exponential decay functions, with time constants as indicated. (B), singleexponential decay time constant $\left(\tau_{\mathrm{REC}}\right)$ plotted as a function of light intensity for $14 \mathrm{WT}$ strain-control rods, $15 \mathrm{Grb}_{14^{-/-}}$rods, and $17 \mathrm{IR}$ knock-down rods. Data are given as means \pm SEM.

was also smaller in $I R$ knock-down rods $(141 \pm 8 \mathrm{~ms})$ than in WT rods (174 $\pm 11 \mathrm{~ms}$ ), and this difference was statistically significant ( $\mathrm{T}$ test, $\mathrm{p}=0.04)$.

In Fig. $5 A$, we plot the mean peak response amplitude as a function of flash intensity for dark-adapted and bleached WT and $I R$ knock-down rods. The curves for $I R$ knock-down rods were displaced to higher intensities by a factor of about 2-4 for darkadapted rods and bleach-adapted rods (see legend to figure), again indicating a decrease in sensitivity.

In Fig. 5B, we examined the effect of steady background light on WT and $I R$ knock-down rods. Sensitivity was calculated by dividing the peak change in current for small-amplitude responses by the flash intensity, in darkness and in the presence of steady background light. The sensitivity in the presence of the background $\left(S_{F}\right)$ was normalized to the sensitivity in the absence of background light $\left(S_{F}^{D}\right.$, and the ratio was plotted as a function of background light intensity. Brighter backgrounds were required to produce a decrease in sensitivity in $I R$ knock-down rods than in WT rods (or Grb14 ${ }^{-1-}$ rods). The data have been fitted with the Weber-Fechner function of the form $S_{F} / S_{F}^{D}=I_{0}$ / $\left(I_{O}+I_{B}\right)$, where $I_{B}$ is the intensity of the steady background light in photons $\mu \mathrm{m}^{-2} \mathrm{~s}^{-1}$ and $I_{0}$ is a constant. Best-fitting values for $I_{0}$ were
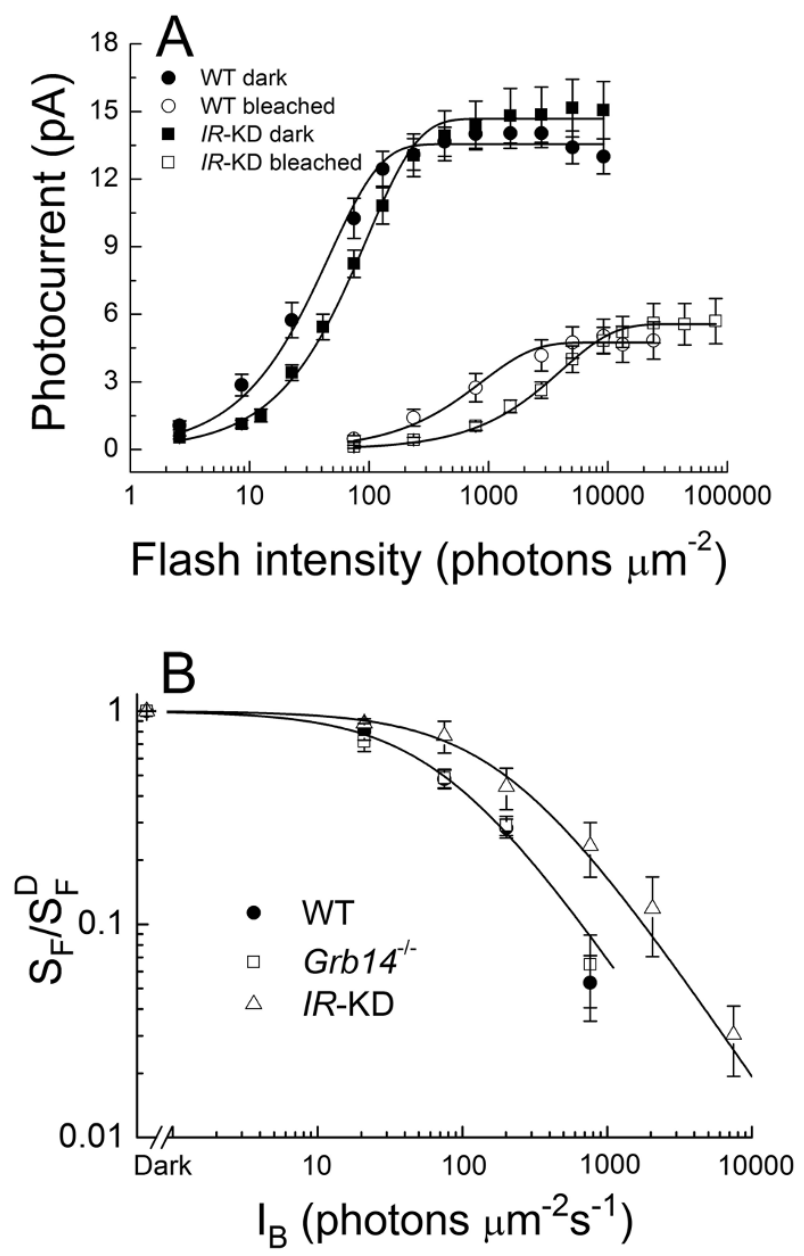

Figure $5 \mid I R$ knock-down rods are less sensitive than WT rods. $A$, response-intensity functions for WT strain control rods and $I R$ knockdown rods (IR-KD), dark-adapted or at steady state after bleaching $50 \%$ of the visual pigment. Data were taken from the same rods as in Fig. 3 and have been fitted with the function $r=r_{\max }[1-\exp (-k I)]$, where $r$ is the mean peak amplitude of the response, $r_{\max }$ is the maximum value of $r, k$ is a constant, and $I$ is the flash intensity in units of photons $\mu \mathrm{m}^{-2}$. Data points are means \pm SEM of 21 dark-adapted WT rods $(\mathbf{)})$ with $r_{\text {max }}=13.6 \mathrm{pA}$ and $k=0.022$ photons $^{-1} \mu \mathrm{m}^{2} ; 9$ bleached WT rods $(\bigcirc)$ with $r_{\max }=4.7 \mathrm{pA}$ and $k=0.0011$ photons $^{-1} \mu \mathrm{m}^{2} ; 16$ dark-adapted $I R$ knock-down rods ( $\left.\mathbf{\square}\right)$ with $r_{\max }=14.7 \mathrm{pA}$ and $k=0.011$ photons $^{-1} \mu \mathrm{m}^{2}$; and 8 bleached $I R$ knock-down rods $(\square)$ with $r_{\text {max }}=5.6 \mathrm{pA}$ and $k=2.4 \times 10^{-4}$ photons $^{-1}$ $\mu \mathrm{m}^{2} . B$, mean sensitivity as a function of background light intensity for 5 WT rods $(\bigcirc), 5$ Grb14 ${ }^{-\prime-}$ rods $(\square)$, and 5 IR knock-down rods $(\Delta)$. Sensitivity $\left(S_{F}\right)$ has been calculated by dividing the peak amplitude of small-amplitude flash responses by the flash intensity and has been normalized to the dark-adapted sensitivity $S_{F}^{D}$. Data points give means \pm SEM and have been fitted with the Weber-Fechner function, $S_{F} / S_{F}^{D}=I_{0} /\left(I_{O}\right.$ $+I_{B}$ ), where $I_{B}$ is the intensity of the steady background light in photons $\mu \mathrm{m}^{-2} \mathrm{~s}^{-1}$ and $I_{0}$ is a constant. Best-fitting values for $I_{0}$ were 73 photons $\mu \mathrm{m}^{-2} \mathrm{~s}^{-1}$ (WT), 68 photons $\mu \mathrm{m}^{-2} \mathrm{~s}^{-1}\left(\right.$ Grb14 $\left.{ }^{-/-}\right)$, and 197 photons $\mu \mathrm{m}^{-2}$ $\mathrm{s}^{-1}$ (IR knock down); only curves for WT and $I R$ knock down are shown.

73 photons $\mu \mathrm{m}^{-2} \mathrm{~s}^{-1}$ for WT rods and 197 photons $\mu \mathrm{m}^{-2} \mathrm{~s}^{-1}$ for $I R$ knock-down rods. The higher value for $I R$ knock-down rods is probably the result of the decreased flash sensitivity of these photoreceptors and the more rapid decay of their responses.

\section{Discussion}

These experiments show that knocking down of the insulin receptor gene produces an acceleration of the time constant of rod response 
decay in both dark-adapted and light-adapted photoreceptors (Figs. 3 and 4), as well as a small decrease in the sensitivity of the rod response both to flashes and to steady background illumination (Figs. 4 and 5). These effects were consistently observed in our recordings and were statistically significant. They cannot be attributed to overexpression of either GAP proteins or PDE $\gamma$, because our quantitative Western blots showed no evidence of a difference in expression of either of these proteins between WT littermate controls and $I R$ knock-down animals (Fig. 2). The decrease in sensitivity that we observe could conceivably be produced in part by a change in the rod collecting area, but some decrease was observed even for singlephoton responses (Fig. 4A). This decrease would have been even larger had we plotted the percent single-photon decrease in current by normalizing single-photon currents to maximum currents. These percent decreases are $5.3 \pm 0.05$ for WT rods $(n=14)$ but $4.3 \pm 0.05$ for $I R$ knock-down rods $(\mathrm{n}=16)$. Thus the presence of IR in a WT rod must normally produce a small enhancement of sensitivity and slowing of the light response.

We have previously shown ${ }^{29}$ that in $I R$ knock-down rods, the outer segment cGMP-gated channels are more sensitive to cGMP and open at a lower concentration of nucleotide. As a result, rod responses should recover more rapidly after light stimulation in $I R$ knockdown rods than in WT rods, because the decay of PDE and subsequent recovery of cGMP concentration would allow the channels to open more rapidly. Our results are consistent with this expectation (Figs. 3 and 4). Because the relationship between photoreceptor current and cGMP concentration is highly nonlinear ${ }^{1-4}$, the increase in channel sensitivity to cGMP might also be expected to produce a small decrease in sensitivity of $I R$ knock-down rods to light, as our experiments also confirm.

The increased affinity of the channels to cGMP would however also be expected to produce an increase in circulating current in darkness. Although the mean current of $I R$ knock-down rods in darkness was somewhat larger than the mean dark current of WT rods, this difference was not significant. A similar observation was made for $G r b 14^{-/-}$rods $^{15}$. It is likely that feedback from the very active guanylyl cyclase in mouse rods acts to minimize the rise in circulating current by altering the concentration of cGMP (see for example reference 43). Future experiments with $I R$ knock-down rods lacking the GCAP proteins may resolve this apparent discrepancy.

We were surprised to discover that the effects of knocking down the insulin receptor were similar on dark-adapted and light-adapted rods (Figs. 3 and 5). This result was unexpected, because our previous experiments have shown that the insulin receptor is activated by light ${ }^{19}$. We would therefore have expected some pronounced difference between dark-adapted and light-adapted responses in WT rods that would not have been seen in $I R$ knock-down rods. Moreover our experiments also indicate that the knocking down of $I R$ produces a modest decrease in the time of rod response saturation $\left(T_{\text {sat }}\right)$ and the limiting time constant $\tau_{D}$, similar to effects we previously reported for deletion of the gene of the Grb14 protein $^{15}$. The decrease in $T_{\text {sat }}$ may be produced at least in part by the decrease in sensitivity, but model calculations show that an increase in channel affinity can by itself also shorten $T_{\text {sat }}{ }^{15}$. The change in $\tau_{D}$ is most readily explained by an acceleration in the decay of light-activated PDE6. An effect on PDE decay could also explain many of the other effects we have observed in $I R$ knock-down rods, including the acceleration of the exponential time constant of decay $\left(\tau_{\mathrm{REC}}\right)$ and the change in sensitivity. An effect on PDE decay might also explain why responses were accelerated even in dark-adapted rods. At present, we have no indication of the mechanism by which the insulin receptor might modulate the decay of PDE.

Our experiments on IR knock-down rods and our previous work on $\mathrm{Grb} 14^{-/-}$rods ${ }^{15}$ suggest that both of these proteins can produce a modest regulation of the rod light response, perhaps by working together as a part of the same non-canonical pathway. Knockiing down the $I R$ gene and deletion of Grb14 produced an acceleration of response decay and a decrease in the limiting time constant, and these effects were similar in both dark-adapted and bleached rods. On the other hand, the knocking down of the IR gene decreased sensitivity (see especially Fig. 5), but no significant change in sensitivity was observed after deletion of Grb14. A role for IR and Grb14 is also indicated by the recent results of McKeown and $\mathrm{Kraft}^{44}$, but the exact mechanism of action of these proteins remains unclear and must await further experimentation.

Our experiments indicate that neither Grb14 nor IR is necessary for the production of the phototransduction cascade that generates the electrical response of the rod. The changes in response sensitivity and kinetics that we have observed are relatively modest. In contrast, studies from our laboratory clearly suggest that IR is essential for photoreceptor survival ${ }^{30}$. The major contribution of IR and perhaps also Grb14 may therefore be in the regulation of the neuroprotective downstream effector cascade.

1. Biel, M., Zong, X., Ludwig, A., Sautter, A. \& Hofmann, F. Structure and function of cyclic nucleotide-gated channels. Rev. Physiol Biochem. Pharmacol. 135, 151-171 (1999).

2. Finn, J. T., Grunwald, M. E. \& Yau, K. W. Cyclic nucleotide-gated ion channels: an extended family with diverse functions. Annu. Rev. Physiol 58, 395-426 (1996).

3. Kaupp, U. B. \& Seifert, R. Cyclic nucleotide-gated ion channels. Physiol Rev. 82, 769-824 (2002).

4. Matulef, K. \& Zagotta, W. N. Cyclic nucleotide-gated ion channels. Annu. Rev. Cell Dev. Biol. 19, 23-44 (2003).

5. Yau, K. W. \& Hardie, R. C. Phototransduction motifs and variations. Cell 139, 246-264 (2009).

6. Hsu, Y. T. \& Molday, R. S. Modulation of the cGMP-gated channel of rod photoreceptor cells by calmodulin. Nature 361, 76-79 (1993).

7. Koutalos, Y. \& Yau, K. W. Regulation of sensitivity in vertebrate rod photoreceptors by calcium. Trends Neurosci. 19, 73-81 (1996).

8. Gordon, S. E. \& Zagotta, W. N. Subunit interactions in coordination of $\mathrm{Ni} 2+$ in cyclic nucleotide-gated channels. Proc. Natl. Acad. Sci. U. S. A 92, 10222-10226 (1995).

9. Karpen, J. W., Brown, R. L., Stryer, L. \& Baylor, D. A. Interactions between divalent cations and the gating machinery of cyclic GMP-activated channels in salamander retinal rods. J. Gen. Physiol 101, 1-25 (1993).

10. Gordon, S. E., Downing-Park, J., Tam, B. \& Zimmerman, A. L. Diacylglycerol analogs inhibit the rod cGMP-gated channel by a phosphorylation-independent mechanism. Biophys. J. 69, 409-417 (1995).

11. Womack, K. B. et al. Do phosphatidylinositides modulate vertebrate phototransduction? J. Neurosci. 20, 2792-2799 (2000).

12. Krajewski, J. L., Luetje, C. W. \& Kramer, R. H. Tyrosine phosphorylation of rod cyclic nucleotide-gated channels switches off $\mathrm{Ca} 2+/$ calmodulin inhibition. J. Neurosci. 23, 10100-10106 (2003).

13. Molokanova, E., Trivedi, B., Savchenko, A. \& Kramer, R. H. Modulation of rod photoreceptor cyclic nucleotide-gated channels by tyrosine phosphorylation. J. Neurosci. 17, 9068-9076 (1997).

14. Gupta, V. K., Rajala, A., Daly, R. J. \& Rajala, R. V. Growth factor receptor-bound protein 14: a new modulator of photoreceptor-specific cyclic-nucleotide-gated channel. EMBO Rep 11, 861-867 (2010).

15. Woodruff, M. L., Rajala, A., Fain, G. L. \& Rajala, R. V. Modulation of mouse rod photoreceptor responses by Grb14 protein. J. Biol Chem 289, 358-364 (2014).

16. Brady, J. D. et al. Interplay between PIP3 and calmodulin regulation of olfactory cyclic nucleotide-gated channels. Proc. Natl. Acad. Sci. U. S. A 103, 15635-15640 (2006).

17. Brunert, D., Klasen, K., Corey, E. A. \& Ache, B. W. PI3Kgamma-dependent signaling in mouse olfactory receptor neurons. Chem Senses 35, 301-308 (2010).

18. Bright, S. R., Rich, E. D. \& Varnum, M. D. Regulation of human cone cyclic nucleotide-gated channels by endogenous phospholipids and exogenously applied phosphatidylinositol 3,4,5-trisphosphate. Mol. Pharmacol. 71, 176-183 (2007).

19. Rajala, A. et al. G-protein-coupled Receptor Rhodopsin Regulates the Phosphorylation of Retinal Insulin Receptor. J. Biol. Chem. 282, 9865-9873 (2007).

20. Rajala, A., Dighe, R., Agbaga, M. P., Anderson, R. E. \& Rajala, R. V. Insulin Receptor Signaling in Cones. J. Biol Chem 288, 19503-19515 (2013).

21. Rajala, R. V., Wiskur, B., Tanito, M., Callegan, M. \& Rajala, A. Diabetes reduces autophosphorylation of retinal insulin receptor and increases protein-tyrosine phosphatase-1B activity. Invest Ophthalmol Vis Sci 50, 1033-1040 (2009).

22. Reiter, C. E. et al. Characterization of insulin signaling in rat retina in vivo and ex vivo. Am. J. Physiol Endocrinol. Metab 285, E763-E774 (2003).

23. Rajala, R. V., Tanito, M., Neel, B. G. \& Rajala, A. Enhanced retinal insulin receptor-activated neuroprotective survival signal in mice lacking the proteintyrosine phosphatase-1B gene. J. Biol. Chem 285, 8894-8904 (2010). 
24. Rajala, R. V. \& Chan, M. D. Identification of a NPXY Motif in Growth Factor Receptor-Bound Protein 14 (Grb14) and Its Interaction with the Phosphotyrosine-Binding (PTB) Domain of IRS-1. Biochemistry 44, 7929-7935 (2005).

25. Bereziat, V. et al. Inhibition of insulin receptor catalytic activity by the molecular adapter Grb14. J. Biol. Chem. 277, 4845-4852 (2002).

26. Depetris, R. S. et al. Structural basis for inhibition of the insulin receptor by the adaptor protein Grb14. Mol. Cell 20, 325-333 (2005).

27. Basavarajappa, D. K., Gupta, V. K., Dighe, R., Rajala, A. \& Rajala, R. V. Phosphorylated Grb14 Is an Endogenous Inhibitor of Retinal Protein Tyrosine Phosphatase 1B, and Light-Dependent Activation of Src Phosphorylates Grb14. Mol. Cell Biol 31, 3975-3987 (2011).

28. Rajala, R. V., Basavarajappa, D. K., Dighe, R. \& Rajala, A. Spatial and temporal aspects and the interplay of Grb14 and protein tyrosine phosphatase-1B on the insulin receptor phosphorylation. Cell Commun. Signal. 11, 96 (2013).

29. Gupta, V. K., Rajala, A. \& Rajala, R. V. Insulin receptor regulates photoreceptor CNG channel activity. Am. J. Physiol Endocrinol. Metab 303, E1363-E1372 (2012).

30. Rajala, A., Tanito, M., Le, Y. Z., Kahn, C. R. \& Rajala, R. V. Loss of neuroprotective survival signal in mice lacking insulin receptor gene in rod photoreceptor cells. J. Biol. Chem. 283, 19781-19792 (2008).

31. Le, Y. Z. et al. Mouse opsin promoter-directed Cre recombinase expression in transgenic mice. Mol. Vis. 12, 389-398 (2006).

32. Kulkarni, R. N. et al. Tissue-specific knockout of the insulin receptor in pancreatic beta cells creates an insulin secretory defect similar to that in type 2 diabetes. Cell 96, 329-339 (1999).

33. Li, G. et al. Nonredundant role of Akt 2 for neuroprotection of rod photoreceptor cells from light-induced cell death. J. Neurosci. 27, 203-211 (2007).

34. Woodruff, M. L. et al. Modulation of phosphodiesterase6 turnoff during background illumination in mouse rod photoreceptors. J. Neurosci. 28, 2064-2074 (2008).

35. Chen, J. et al. Channel modulation and the mechanism of light adaptation in mouse rods. J. Neurosci. 30, 16232-16240 (2010).

36. Chen, C. K. et al. Modulation of mouse rod response decay by rhodopsin kinase and recoverin. J. Neurosci. 32, 15998-16006 (2012).

37. Nymark, S., Frederiksen, R., Woodruff, M. L., Cornwall, M. C. \& Fain, G. L. Bleaching of mouse rods: microspectrophotometry and suction-electrode recording. J. Physiol 590, 2353-2364 (2012).

38. Woodruff, M. L., Lem, J. \& Fain, G. L. Early receptor current of wild-type and transducin knockout mice: photosensitivity and light-induced $\mathrm{Ca} 2+$ release. J. Physiol 557, 821-828 (2004).

39. Pepperberg, D. R. et al. Light-dependent delay in the falling phase of the retinal rod photoresponse. Vis Neurosci. 8, 9-18 (1992).

40. Chen, C. K. et al. Slowed recovery of rod photoresponse in mice lacking the GTPase accelerating protein RGS9-1. Nature 403, 557-560 (2000).
41. Tsang, S. H. et al. GAP-independent termination of photoreceptor light response by excess gamma subunit of the cGMP-phosphodiesterase. J. Neurosci. 26, 4472-4480 (2006).

42. Sundermeier, T. R. et al. R9AP overexpression alters phototransduction kinetics in iCre75 mice. Invest Ophthalmol Vis Sci 55, 1339-1347 (2014).

43. Tsang, S. H. et al. Effect of the ILE86TER mutation in the gamma subunit of cGMP phosphodiesterase (PDE6) on rod photoreceptor signaling. Cell Signal. 24, 181-188 (2012).

44. McKeown, A. S. \& Kraft, T. W. Adaptive potentiation in rod photoreceptors after light exposure. J. Gen. Physiol 143, 733-743 (2014).

\section{Acknowledgments}

This work was supported by NIH/NEI grants EY016507 and EY00871 (to RVSR) and EY01844 (to GLF). The authors thank Dr. Robert S. Molday (University of British Columbia, Canada) for providing channel antibodies, Dr. Theodore G. Wensel (Baylor College of Medicine, Houston) for providing antibodies against RGS9-1, Gß5, and R9AP and Dr. Seifollah Azadi (University of Oklahoma, Oklahoma) for providing GC1 and CGAP1 antibodies.

\section{Author contributions}

R.R. and G.F. designed research. M.W., A.R. and R.R. performed the research; M.W., A.R., G.F. and R.R. analyzed the data; and R.R. and G.F. wrote the paper.

\section{Additional information}

Supplementary information accompanies this paper at http://www.nature.com/ scientificreports

Competing financial interests: The authors declare no competing financial interests.

How to cite this article: Woodruff, M.L., Rajala, A., Fain, G.L. \& Rajala, R.V.S. Effect of Knocking Down the Insulin Receptor on Mouse Rod Responses. Sci. Rep. 5, 7858; DOI:10.1038/srep07858 (2015)

This work is licensed under a Creative Commons Attribution-NonCommercialShareAlike 4.0 International License. The images or other third party material in this article are included in the article's Creative Commons license, unless indicated otherwise in the credit line; if the material is not included under the Creative Commons license, users will need to obtain permission from the license holder in order to reproduce the material. To view a copy of this license, visit http:// creativecommons.org/licenses/by-nc-sa/4.0/ 